\title{
Seasonal variations of terrestrial Dissolved Organic Carbon loading in response to rainfall events
}

\author{
Qiao Huijiao ${ }^{1,2, a}$, Xu Jian ${ }^{1,3}$, Yan Jilin $^{1,3}$ \\ ${ }^{1}$ Jiangxi Normal University, 330022 Nanchang Jiangxi, China \\ ${ }^{2}$ Central Michigan University, 48858 Mt Pleasant, MI, U.S. \\ ${ }^{3}$ Key Lab of Poyang Lake Wetland and Watershed Research, Ministry of Education, 330022 Nanchang Jiangxi, \\ China
}

Keywords: DOC; Rainfall; Agricultural land-uses; Antecedent precipitation; Different Seasons.

\begin{abstract}
Dissolved organic carbon (DOC) loading from lands to rivers in response to rainfall events are the major carbon sources to aquatic ecosystem. We used high-resolution measurements to determine the runoff exports of DOC from the Chippewa River and watershed which was largely dominated by agricultural land-uses. It was found that DOC concentrations in spring were higher than in autumn and discharges in spring affected by snowmelt were larger and varied more widely than in autumn in this mixed watershed. We focused on the effect of antecedent 10-day rainfall on DOC variation and exports for the different magnitudes rainfall events. It showed that the antecedent precipitation (field moisture conditions) greatly determined the extent of DOC export. It was also shown that the DOC-Discharge distributions for storm-events were generally asymmetric, whereby they were positively skewed and it was greatly different between different seasons.
\end{abstract}

\section{Introduction}

The export of organic carbon in runoff has important environmental and ecological consequences for terrestrial, aquatic and atmospheric ecosystems [Gurbir et al., 2013; Butman and Raymond, 2011]. Dissolved organic carbon (DOC) is one of the largest carbon pools in aquatic systems [Carlson et al., 1994]. DOC is a starting point for the aquatic food chain [Findlay, 2010], influences water quality [Kaplan et al., 2006] and protects against harmful UV radiation [Williamson and Zagarese, 1994]. The flux of DOC plays a significant role in global carbon cycling and regional budget of organic carbon entering the oceans [Butman and Raymond, 2011].

Most of the DOC exported from catchments occurs during storm events [Dalzell et al., 2007; Inamdar et al., 2006; Joanna et al., 2007; Jeong et al., 2012]. Storm events that constituted only 10\%$20 \%$ of the total study period contributed to $>70 \%$ of DOC exports [Oeurng et al., 2011]. $86 \%$ of annual DOC is exported during rainfall events in forested watersheds in the Northeast [Raymond and Saiers, 2010]. Terrestrial organic carbon export is ultimately controlled by land use, topography and

${ }^{\mathrm{a} C}$ Corresponding author : huijiaoqiao@163.com 
climate [Emma et al., 2013]. Croplands and forested lands together account for $40 \%$ of the Earth's land surface [Foley et al., 2005]. Although many researches focus on agricultural, forested and upland peatland [Joanna et al., 2007; Aitkenhead-Peterson et al., 2005; Worrall et al., 2002; Philippe et al., 2008], there are large variations in the DOC export on spatial and temporal scales [Hope et al., 1994; Laudon et al., 2004a]. It needs further research to study how different landscapes and climate influence carbon cycling.

In this study, our objective is to characterize DOC transported during different magnitude and intensity storm events from mixed land-uses in Northeast USA, and illustrates different responses in different seasons.

\section{Materials and methods}

\subsection{Study Area}

The watershed, Chippewa River, used in this study is located in Mount Pleasant, Central Michigan, US. Central Michigan has a temperate continental and humid climate. The long term average spring temperature in Mount Pleasant is 6.48 。 $\mathrm{C}$ and autumn temperature is 9.08 。 . The average precipitation in spring is $69.34 \mathrm{~mm}$ and the autumn is $75.44 \mathrm{~mm}$ (United States Geography, available at http://countrystudies.us/united-states/weather/michigan/). The snowpack covers the ground intermittently from late December to late March. The average annual discharge rate is $7.19 \mathrm{~m} 3 / \mathrm{s}$ with an average Spring discharge rate of $23.88 \mathrm{~m} 3 / \mathrm{s}$ and average Autumn discharge rate of $5.97 \mathrm{~m} 3 / \mathrm{s}$ for water years from 1931 to 2013 (USGS NWIS, available at http://waterdata.usgs.gov). The study area is a $1037 \mathrm{~km} 2$ mixed watershed. Local land use is approximately $45 \%$ agriculture, $40 \%$ forest, small percentages of residential and other land uses (open water, wetland).

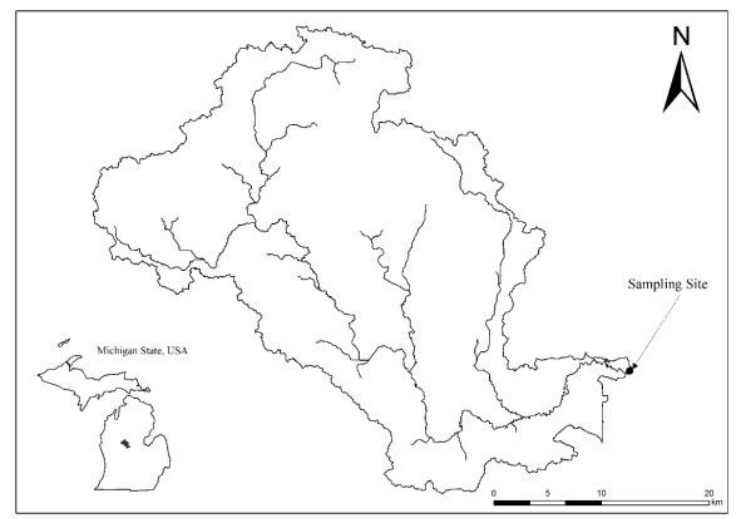

Figure 1. Location of the study site in Mount Pleasant, MI

\subsection{Event Sampling and DOC Analysis}

Five storm events were analyzed for this watershed from the period of March 2013 to April 2015. During storm events, runoff samples were collected from the shore using an auto-sampler (ISCO 6712) approximately $100 \mathrm{~m}$ from the USGS gauge station (Fig.1). The samples were collected at 1 to 2 hour interval and discharge was recorded at 15 -min interval by the gauge station. Samples were filtered using Whatman GF/F $0.7 \mu \mathrm{m}$ filters as soon as possible owing to the unstable nature of aquatic humic substances. When delays in analysis were unavoidable, the filtered samples were acidified with $2 \mathrm{~N}$ HCL and then were kept in refrigerated at 4 。C. DOC concentrations were determined using a Shimadzu TOC-V-L analyzer. All of the sampling information was organized in Table 1.

\section{Results and discussion}

Over two years of sample collection, DOC concentrations between different rainfall events ranged from 4.0 to $9.48 \mathrm{mg} \mathrm{L-1} \mathrm{(Table} \mathrm{1).} \mathrm{The} \mathrm{concentration} \mathrm{of} \mathrm{DOC} \mathrm{in} \mathrm{streams} \mathrm{can} \mathrm{range} \mathrm{from}<1$ to about 50mg L-1 [Mulholland, 2003]. The mixed-land-use we studied fell within this range, with most measurements $<9.48 \mathrm{mg} \mathrm{L}-1$. Although the discharges varied from 5.7 to $37.38 \mathrm{~m} 3 \mathrm{~s}-1$, the average 
DOC concentrations were remarkably similar among all samples, varying by $<3 \mathrm{mg} \mathrm{L}-1$. For all of these samples (Table 1), average DOC concentration in spring was higher than in autumn. For this mix-land, corn would be harvested from the fields in autumn, leaving stalk residues on the field. For the whole winter, the stalk residues and abundant deciduous were covered by snow and decomposed by microbes so that the allochthonous DOC entering rivers was abundant.

Table 1. DOC concentration, Discharge, Rainfall Data collected during sampling and 10-day antecedent rainfall

\begin{tabular}{|c|c|c|c|c|c|c|}
\hline Event date & $\begin{array}{c}\text { DOC } \\
\text { range(mg/L) }\end{array}$ & $\begin{array}{c}\text { Discharge } \\
\text { range(m3/s) }\end{array}$ & $\begin{array}{c}\text { Sample } \\
\text { number }\end{array}$ & $\begin{array}{c}\text { Average DOC } \\
\text { concentration(mg/L) }\end{array}$ & $\begin{array}{c}\text { Rainfall during } \\
\text { sampling(mm) }\end{array}$ & $\begin{array}{c}\text { 10-day } \\
\text { antecedent } \\
\text { rainfall(mm) }\end{array}$ \\
\hline $3 / 14 / 2013$ & $7-9$ & $17.1-22$ & 24 & 7.78 & 0.01 & 10.92 \\
\hline $4 / 2 / 2014$ & $6.02-9.48$ & $20-24$ & 22 & 6.61 & 0.508 & 2.03 \\
\hline $10 / 2 / 2014$ & $4.0-9.14$ & $5.7-13$ & 72 & 6.00 & 40.89 & 2.54 \\
\hline $11 / 11 / 2014$ & $4.5-6.5$ & $8.2-9.1$ & 48 & 5.16 & 3.30 & 14.22 \\
\hline $4 / 7 / 2015$ & $5.03-8.89$ & $9.20-37.38$ & 120 & 6.83 & 51.56 & 18.29 \\
\hline
\end{tabular}

For the storm on April 2, 2014 (Fig. 2b) and November 11, 2014 (Fig. 2f), we just sampled on the falling limb of the storm hydrographs and both of them presented that DOC closely varied with the discharge. There was $2.03 \mathrm{~mm} 10$-day antecedent rainfall and $0.508 \mathrm{~mm}$ rainfall during sampling on April 2, 2014. And the concentration tiny fluctuated with discharge. Similarly, although there was $14.22 \mathrm{~mm} 10$-day antecedent rainfall and $3.30 \mathrm{~mm}$ rainfall during sampling on November 11, 2014, DOC concentration with the discharge changed slightly. For the storm on October 2, 2014 (Fig. 2d), it showed DOC peaked slightly after the peak of the discharge and DOC dilution as the storm reached its maximum intensity in the earlier storm. Some researches also got the same results (Inamdar et al. 2004; Pillippe et al. 2008;). But DOC concentrations increased and peaked again after temporary decreasing. For the storm on April 7, 2015 (Fig. 2c), although it was also the meteoric water, the variation of DOC concentration showed the opposite result in the early storm when compared with the storm on October 2, 2014. DOC peaked slightly before the peak in discharge. DOC concentration closely increased with the rising discharge before it arrived at the peak. After that, DOC concentration dramatically decreased, however the discharge sustained growth for a while and then decreased. The storm on March 14, 2013 (Fig. 2a) showed the similar trend but it only went through a temporary decreasing and rapidly peaked again.

Henry and others (2008) observed the relationship between DOC concentration and discharge was temporally dynamics and largely driven by changes in regional moisture conditions. For the hysteresis of DOC in October 2, 2014, there was only $2.54 \mathrm{~mm} \mathrm{10-day} \mathrm{antecedent} \mathrm{precipitation} \mathrm{on} \mathrm{September} \mathrm{29,}$ 2014 and compared with the $40.89 \mathrm{~mm}$ heavy storm we studied in October 2, 2014, the antecedent precipitation barely had effect on it. Thus, this hysteresis can be attributed to the large volume of meteoric water, and discharge clearly increased at a rate faster than DOC could be leached from the vegetation residues or soil. DOC concentrations decreased later in the storm. Several characteristics potentially contribute to this variation, it was associated with exhaustion of organic matter on the surface and DOC-poor water from deeper mineral soil on hillslope after the soil moisture deficits had been satisfied [Hood et al., 2006].After the connection between the organic matter and soil moisture, DOC in deep ground water was easily flushed so that DOC concentration increased in a short time. However, there was $18.29 \mathrm{~mm}$ constant rainfall for antecedent 10 days in April 7, 2015. It accounted to $33 \%$ of the total rainfall during sampling. Chow and others (2006) reported that a significant of DOC was produced in the surface soil under constantly flooded hydrological conditions. And the snowmelt in spring made soil moisture levels increased, greater contact with surface soil horizons and hydrological connectivity would be developed so that DOC would be easily exported by storm events. Thus the intense precipitation we studied quickly flushed the near-stream source of DOC so that DOC 
concentration immediately peaked prior to the hydrograph peak. Similarly, for the sampling in March 14 , 2013, there was $10.92 \mathrm{~mm} 10$-day antecedent precipitation and only $0.01 \mathrm{~mm}$ rainfall during sampling. But the 10-day antecedent discharge presented an obvious runoff, which only can be explained by lots of snowmelt. And the rising of near-stream water tables easily flushed out old DOCrich water previously stores in the soil [Bishop et al., 2004; Laudon et al., 2004b]. Therefore, although there was light rain during sampling, the 10-day antecedent rain and snowmelt made soil saturated and increased hydrological connectivity of the landscape to the stream so that DOC concentration highly increased with discharges in the rising limb during the storm event.

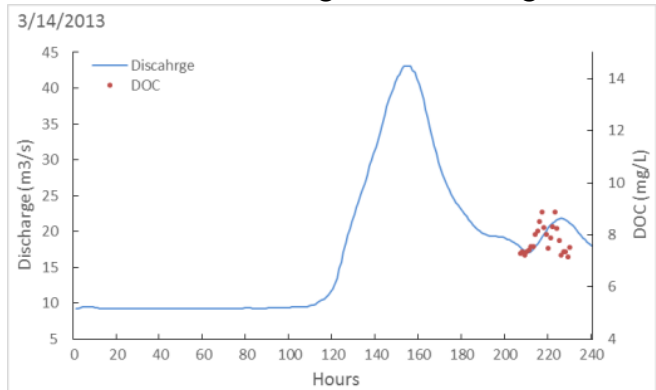

a

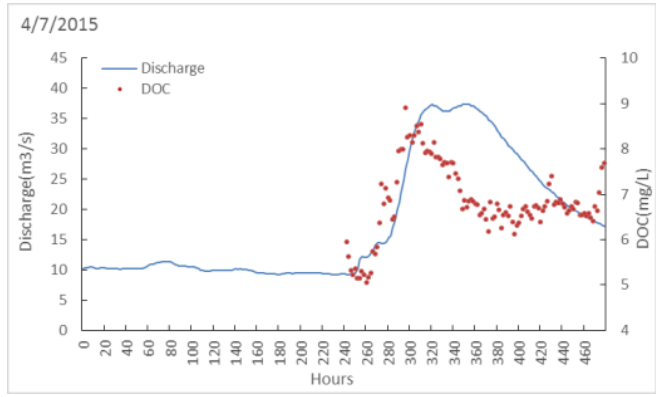

$\mathrm{c}$

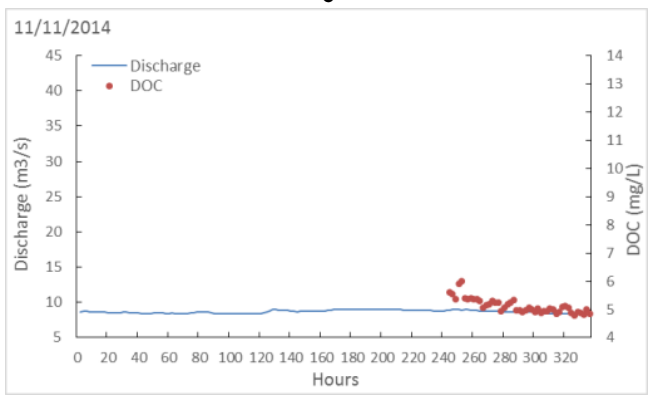

$\mathrm{e}$

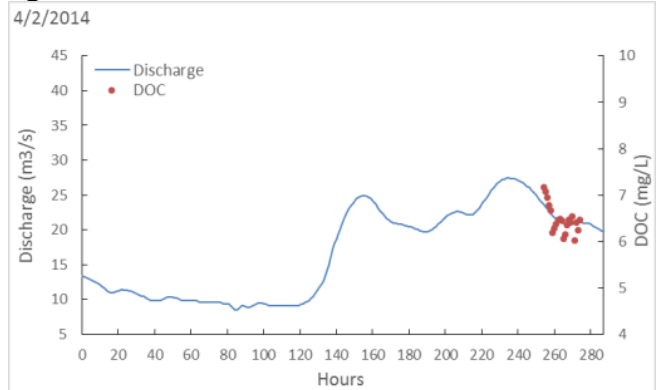

b

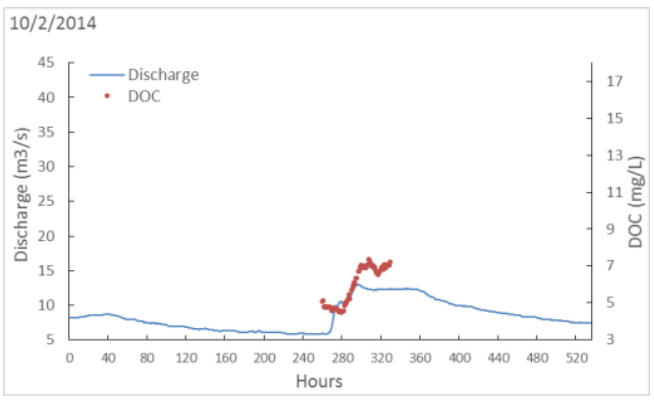

d

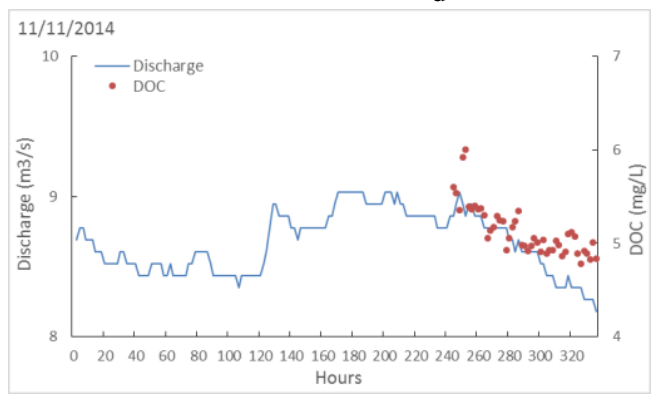

f

Figure 2. DOC concentration and discharge for the five storm events. The discharges extended forward for ten days. The discharge in figure 2e slightly fluctuated during sampling so that we zoomed in it in figure $2 \mathrm{f}$.

\section{Conclusion}

This study catchment is covered mostly by agriculture and forest with minor proportion of wetland and urban areas and the snowmelt in spring is a major hydrological event in this region. Thus, the results can be assumed to be representative for mixed land-use dominated by agricultural parts of the northern region. 
The average DOC concentrations in spring were higher than in autumn during all of the sampling events. Rainfall events due to climate change increased the export of terrigenous DOC. In Chippewa River watershed, the principal factor controlling DOC loading is stream discharge with seasonal effects.

In addition to the effects of flow and seasonal on DOC concentration and export, there was also the effect of antecedent precipitation or snowmelt leading to large discharges (field moisture conditions) that determining the extent of DOC export from this mixed land use dominated by agriculture.

The relationship between DOC concentration and discharge was temporally dynamics. Based on the simple relationship between them would lead to a significant deviation of DOC flux and carbon budget. Hence, we need to take more scientific methods to reverse the relationship between DOC concentration and discharge when DOC concentration is not comprehensive for the storm event.

\section{Acknowledgements}

This research was conducted with the support of Innovation Fund for Graduates of Jiangxi Province of China (No.YC2014-S154), Overseas Visiting Program for Graduates of Jiangxi Normal University of China and Geography Department of Central Michigan University, U.S. Support provided by Professor Tian Y.Q in Central Michigan University during field work and data acquisition is acknowledged.

\section{References}

1. Bender, M. A., T. R. Knutson, R. E. Tuleya, J. J. Sirutis, G.A. Vecchi, S. T. Garner, and I. M. Held: Modeled impact of anthropogenic warming on the frequency of intense Atlantic hurricanes, Science, 327(5964), 454-458 (2010).

2. Bishop, K., J. Seibert, S. Koher, and H. Laudon: Resolving the double paradox of rapidly mobilized old water with highly variable responses in runoff chemistry, Hydrol. Processes, 18(1), 185-189(2004).

3. Byungman Yoon and Peter A.Raymond: Dissolved organic matter export from a forested watershed during hurricane Irene(2012).

4. Butman,D.,P.A.Raymond: Significant efflux of carbon dioxide from streams and rivers in the United states,Nat.Geosci.,4,839-842(2011).

5. Cralg A. Carlson, Hugh W. Ducklow \& Anthony F. Michaels: Annual flux of dissolved organic carbon from the euphotic zone in the northwestern Sargasso Sea. Letters to nature (1994).

6. Dalzell BJ,Filley TR,Harbor JM: The role of hydrology in annual organic carbon loads and terrestrial organic matter export from a Midwestern agricultural watershed. Geochim Cosmochim Acta,71(6):1448-1462(2007).

7. Dawson, J.J.C., Billett, M.F., Neal, C., Hill, S.: A comparison of particulate, dissolved and gaseous carbon in two contrasting upland streams in the UK. Journal of Hydrology 257 (1-4),226246(2002).

8. David L. Correll, Thomas E.Jordan and Donald E. Weller: Effects of precipitation, air temperature ,and land use on organic carbon discharges from Rhode River watersheds. Water, Air, and Soil Pollution,128:139-159(2001).

9. Emma Caverly,James M.Kaste, Gregory S. Hancock, and Randolph M. Chambers: Dissolved and particulate organic carbon fluxes from an agricultural watershed during consecutive tropical storms.Geophysical researcha letters,40,5147-5152(2013).

10. Eran Hood, Michael N. Gooseff, and Sherri L. Johnson, Changes in the character of stream water dissolved organic carbon during flushing in three small watersheds, Oregon. Journal of geophysical research, 111, G01007(2006). 
11. Findlay S, WH McDowell, D Fischer, ML Pace, N Caraco, SS Kaushal, and KC Weathers: Total carbon analysis may overestimate organic carbon content of fresh waters in the presence of high dissolved inorganic carbon. Limnol. Oceanogr.:Methods 8,196-201 (2010).

12. Foley,J, A.,et al: Global consequences of land use, Science, 309(5734),570-574(2005).

13. F. Worrall,T.P. Burt, R.Y.Jaeban, J.Warburton and R. Shedden: Release of dissolved organic carbon from upland peat. Hydrological processes, 16,3487-3504(2002).

14. Groisman, P.Y., R.W. Knight, T. R. Karl,D. R. Easterling,B. Sun, and J.H.Lawrimore: Contemporary changes of the hydrological cycyle over the contiguous United States: Trends derived from in situ observations, J. Hydrometeorol., 5, 64-85(2004).

15. Groisman, P.Y., R.W. Knight, D. R. Esterling, T.R. Karl, G.C. Hegerl, and V. N.Razuvaez: Trends in intense precipitation in the climate record, J. Clim., 18,1326-1350(2005).

16. Gurbir Singh Dhillon and Shreeram Inamdar: Extreme storms and changes in particulate and dissolved organic carbon in runoff: Enterning uncharted waters? ,Geophysical research letters,40,1322-1327(2013).

17. Hope,D.,M.F.Billett, and M.S.Cresser: A review of the export of carbon in river water: Fluxes and progresses,Environ.Pollut.,84(3),301-324(1994).

18. Inamdar, S.P., O’Leary, N., Mitchell, M.J., Riley, J.T.: The impact of storm events on solute exports from a glaciated forested watershed in western New York, USA. Hydrological Processes 20(16), 3423-3439 (2006).

19. Inamadar SP, SF Christopher, MJ Mitchell: Export mechanisms for dissolved organic carbon and nitrate during summer storm events in a glaciated forested catchment in New York, USA. Hydrol Process 18:2651-2661(2004).

20. Jeong,J. J.,S. Bartsch,J. H. Fleckenstein,E. Matzner,J. D. Tenhunen,S. D. Lee,S.K.Park, and J.H.Park,Differential storm responses of dissolved and particulate organic carbon in a mountainous headwater stream, investigated by high-frequency, in situ optical measurements, J. Geophys. Res., 117, G03013 (2012).

21. Joanna M.Clark, Stuart N.Lane,Pippa J.Chapman et al., : Export of dissolved organic carbon from an upland peatland during storm events: Implications for flux estimates. Journal of Hydrology347,438-447(2007).

22. J. A. Aitkenhead-Peterson, J.E. Alexander, T.A. Clair: Dissolved organic carbon and dissolved organic nitrogen export from forested watersheds in Nova Scotia: Identifying controlling factors, Global biogeochemical cycles, 19,Gb4016(2005).

23. Kaplan LA, JD Newbold, DJV Horn, CL Dow, AK Aufdenkampe, and JK Jackson: Original matter transport in New York City drinking-water-supply

watersheds,J.N.Am.Benthol.Soc.,25(4),912-927(2006).

24. Laudon,H.,S.Kohler,and I. Buffam: Seasonal TOC export from seven boreal catchments in northern Sweden,Aquat.Sci.,66(2),223-230(2004a).

25. Laudon, H., J. Seibert, S. Kohler, and K. Bishop: Hydrological flow paths during snowmelt:Congruence between hydrometric measurements and oxygen 18 in meltwater, soil water, and runoff, Water Res. Res., 40, W03102(2004b).

26. McKnight DM, Boyer EW, Westerhoff PK, Doran PT, Kulbe T, Andersen DT: Spectral fluorometric characterization of dissolved organic matter for indication of precursor organic material and aromaticity. Limnol Oceanogr 46(1):38-48(2001).

27. Mulholland, P.J: Large-scale patterns in dissolved organic carbon concentration, flux, and sources. In: S. E. G. Findlay and R. L. Sinsabaugh (eds.), Aquatic Ecosystems: Interactivity of Dissolved Organic Matter, Academic Press, New York, pp.139-159(2003).

28. Oeurng,C.s., A. Sauvage, E. Coynel, H. E. Maneux, and J. M. Sanchezperez: Fluvial transport of suspended sediment and organic carbon during flood events in a large agricultural catchment in soutjwest France, Hydrol. Process., 25, 2356-2378(2011).

29. Philippe Vidon, Laura E. Wanger, Emmanuel Soyeux: Changes in the character of DOC in streams during storms in two Midwestern watersheds with contrasting land uses.Biogeochemistry,88:257-270 (2008). 
30. Raymond,P.A., and J.E.Saiers: Events controlled DOC export from forested watersheds,Biogeochemistry,100(1-3),197-209(2010).

31. Sidney B.Morkert, William D.Swink, James G.Seelye: Evidence for early Metamorphosis of sea lampreys in the Chippewa River,Michigan. North American Journal of Fisheries Management 18:966971(1998).

32. Tranvik, L.J., Jasson, M., 2002. Climate change - terrestrial export of organic carbon. Nature 415, 861-862.

Todd V. Royer and Mark B. David, 2005. Export of dissolved organic carbon from agricultural streams in Illinois, USA. Aquatic Sciences, 67,465-471.

33. Williamson,C.E., and H.E.Zagarese: The impact of UV-B radiation on pelagic freshwater ecosystems, Arch. Hydrobiol. Beih, 43, 9-11(1994). 